\title{
Osteosarcoma with Secondary Pulmonary Metastasis - A Case Report
}

\author{
Vikram Khanna* \\ Department of Orthopaedics, Ranjana Hospital, Allahabad
}

Submission: December 15, 2016; Published: January 27, 2017

*Corresponding author: Vikram Khanna, Department of Orthopaedics, Ranjana Hospital, Allahabad, India, Tel: +91 9335106867;

Email: 86.khanna@gmail.com

\begin{abstract}
Osteosarcoma also called as osteogenic sarcoma is a malignant tumour caused by the increase in the number of osteoid cells. It is the second most common bone tumour. Most common presentation is in the second decade of life but ours is a rare case due to old age of presentation. A $55 \mathrm{yr}$ old female patient came with the complaints of painful massive swelling in the left knee along with the inability to walk since $1 \frac{1}{2} \mathrm{years}$. Initially the pain was relieved on medication and rest but later she developed night pain. Since the last 4 months the swelling has been rapidly increasing in size. On X-Ray Knee a Pathological fracture of the distal femur was seen. X-Ray Chest and HRCT thorax showed multiple massive Cannon Ball Appearances in bilateral lungs. Histopathology of the biopsy sample confirmed the diagnosis of osteosarcoma.
\end{abstract}

Keywords: Osteosarcoma; Cannon ball metastasis; Osteoid cells

\section{Introduction}

Osteosarcoma is the second most common primary malignancy accounting for about $20 \%$ of the cases. Osteosarcoma mainly occurs in the $2^{\text {nd }}$ decade of life. Here we present a case of osteosarcoma in a patient with secondary metastasis in the $6^{\text {th }}$ decade of life.

\section{Case Report}

\section{Presenting complaints}

A 55yrfemale came with the c/o
a) Swelling around the knee joint for 18 months
b) Pain in the knee joint for 18 months

Pt. was apparently alright 18 months back when she started having pain in her left knee for which she was on analgesics. Patient was relieved on medication \& aggravated after the effect of the medication decreased. Pain and swelling was so much that the patient was unable to straighten her knee. Pt. also complained of severe night pains. An open biopsy was performed which confirmed the diagnosis.

\section{Clinical features (Figure 1 - 3)}

Swelling with maximum diameter of about $13 \mathrm{~cm}$ present Local temperature raised. Firm to hard swelling fixed to the bone and skin was seen which was diffused. Movement at the knee joint is painful and restricted.

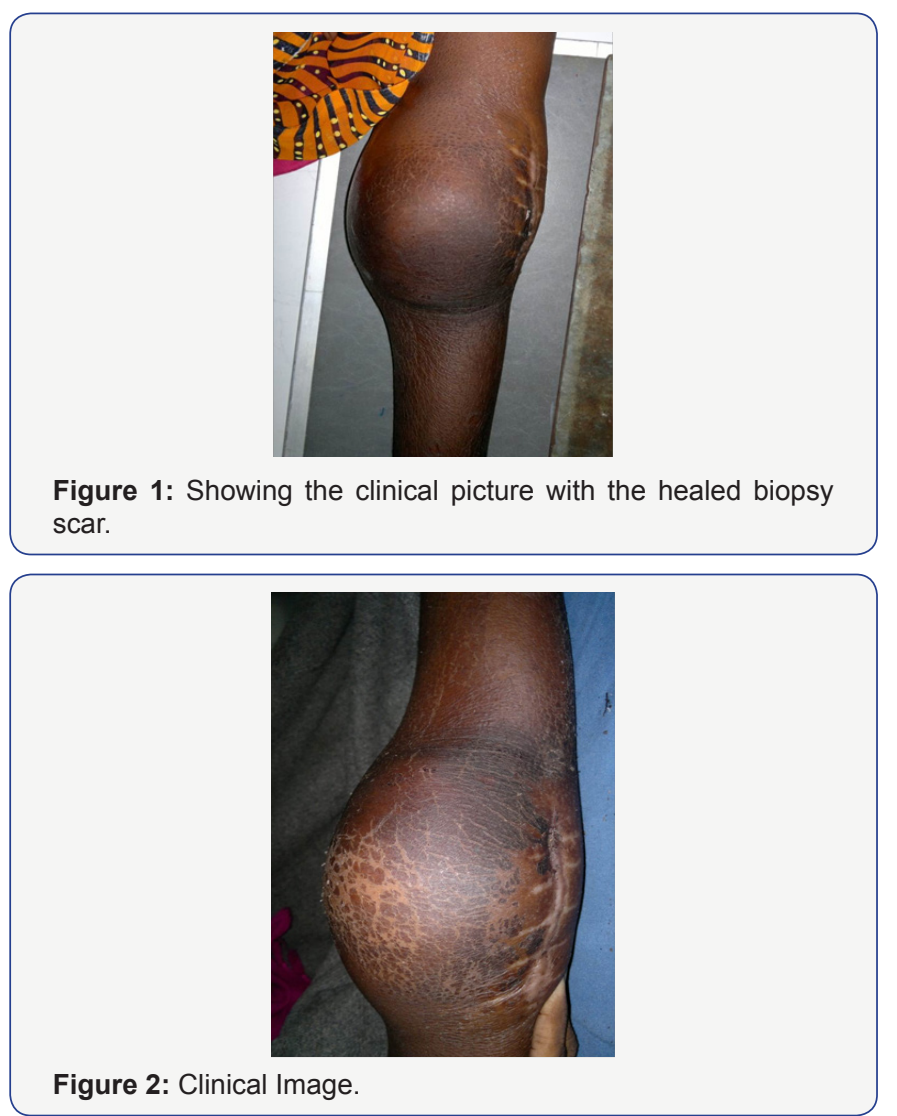




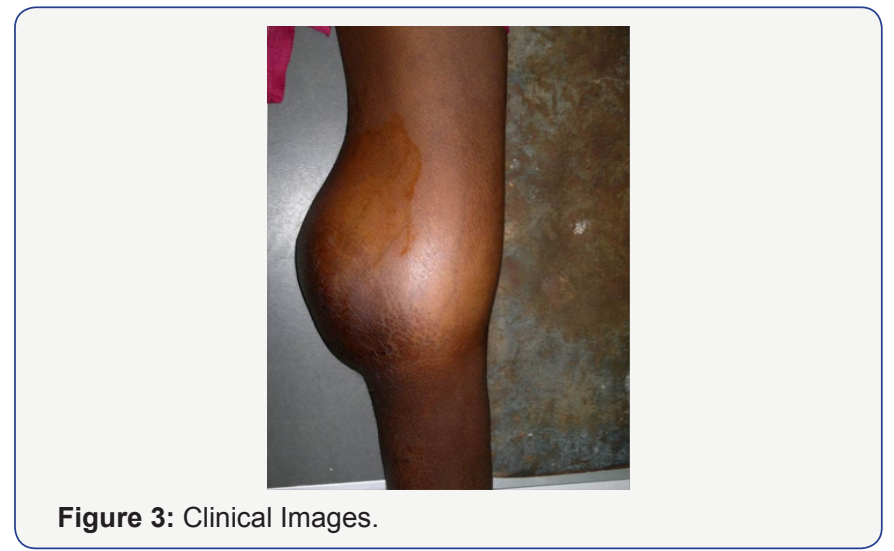

Translucency absent Biopsy scar present.

\section{Investigations}

\section{Haemoglobin}
a) $5.0 \mathrm{gm} \%$ M: $01 \%$
d) ESR: $64 \mathrm{~mm}$ in $1^{\text {st }}$ hour
e) Serum Urea: $24 \mathrm{mg} / \mathrm{dl}$
f) Serum Creatinine: $1.20 \mathrm{mg} / \mathrm{dl}$

b) Total Leucocyte Count: 11,000 Cells/cumm.

c) Differential Leucocyte Count: N: 90\%, L: 08\%, E: 01\%,

\section{Liver function test}
a) Serum Bilirubin (Total): $0.47 \mathrm{mg} / \mathrm{dl}$
b) SGPT/ALT: $21.3 \mathrm{IU} / \mathrm{L}$
c) SGOT/AST: $16.9 \mathrm{IU} / \mathrm{L}$
d) Serum Alkaline Phosphate: $72 \mathrm{IU} / \mathrm{L}$
e) Serum Sodium: $141 \mathrm{mmol} / \mathrm{L}$
f) Serum Potassium: $4.3 \mathrm{mmol} / \mathrm{L}$
g) HIV, HCV And HBs Ag: negative
h) ELISA for TB: negative
i) USG Whole Abdomen: Normal.

\section{Radiological Investigations}

a) X-ray Left Knee (Figure 4\& 5): There is evidence of a destructive lesion showing mixed lytic and sclerotic areas with ill-defined edges in lower end of left femur with associated periosteal reaction and increased soft tissue shadow along with fracture of distal end of left femur.

b) MRI Left Knee (Figure 6-10): There is a large expansile destructive bony mass with associated huge soft tissue component arising from lower end of left femur. There is intraarticular extension in the knee joint with involvement of upper end of tibia. The mass is predominantly hyperintense on T2 \& isointense on T1 with multiple septations \& areas of necrosis. Soft tissue is showing extension into the surrounding muscle planes. Popliteal artery is displaced laterally showing normal flow. Findings are suggestive of neoplastic eitiology (most likely malignant -? Osteosarcoma).

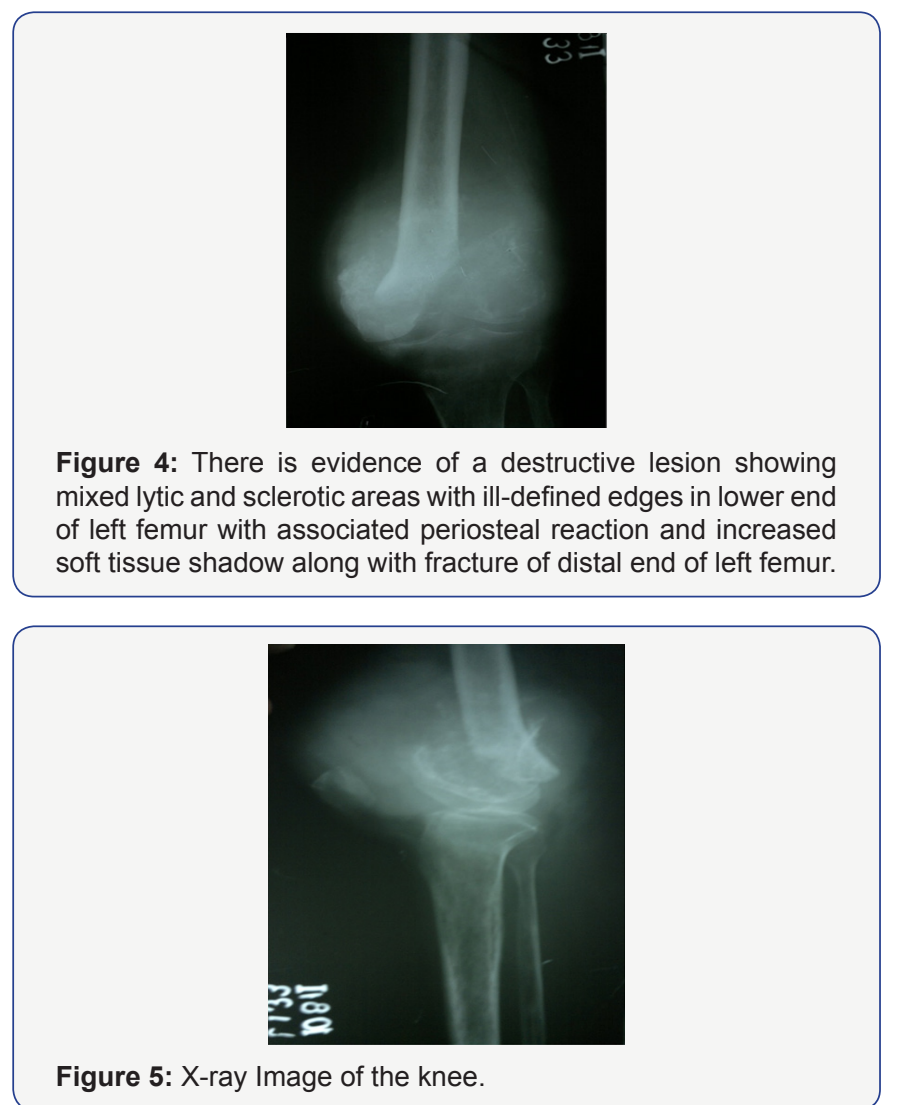

Figure 5: X-ray Image of the knee.
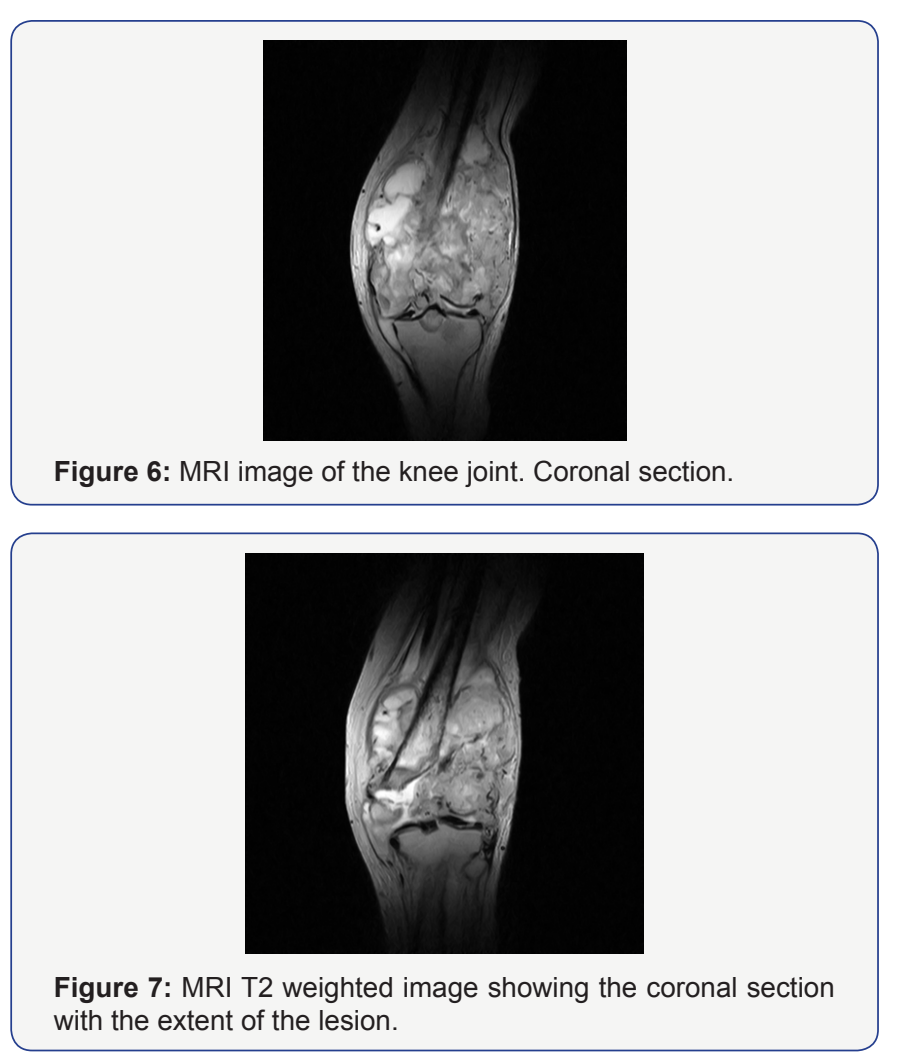


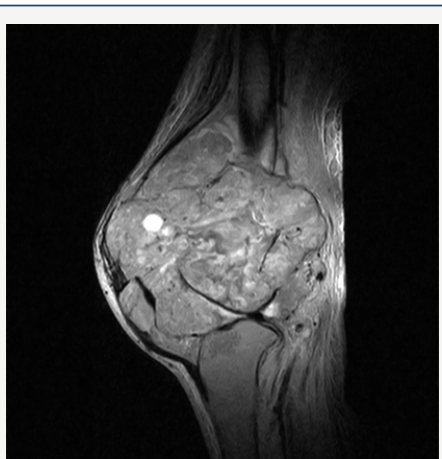

Figure 8: T2 weighted sagittal section of the MRI.

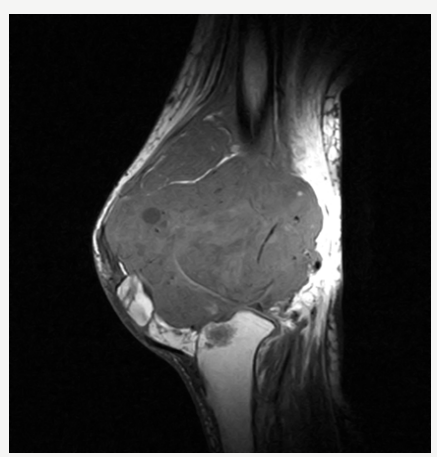

Figure 9: T1 weighted sagittal section of the knee joint.

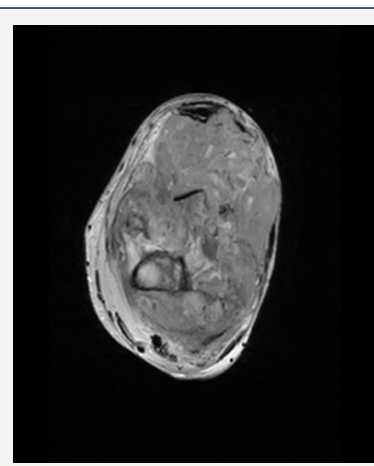

Figure 10: Axial Section of MRI showing the extent of the lesion

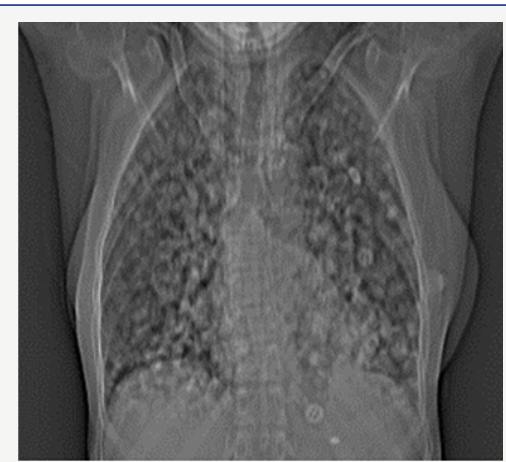

Figure 11: Showing multiple round nodular radio paque shadows are noted in both lung fields most likely suggestive of multiple pulmonary metastasis.

c) Chest X Ray PA view (Figure 11): Multiple round nodular radiopaque shadows are noted in both lung fields most likely suggestive of multiple pulmonary metastasis.

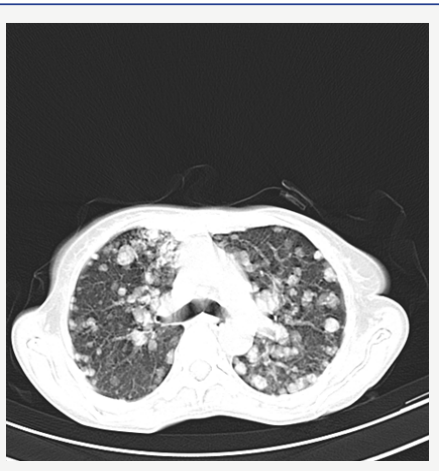

Figure 12: Showing multiple small to moderate size "Canon Ball" Opacities scattered in both lung fields suggestive of multiple Pulmonary Metastasis.

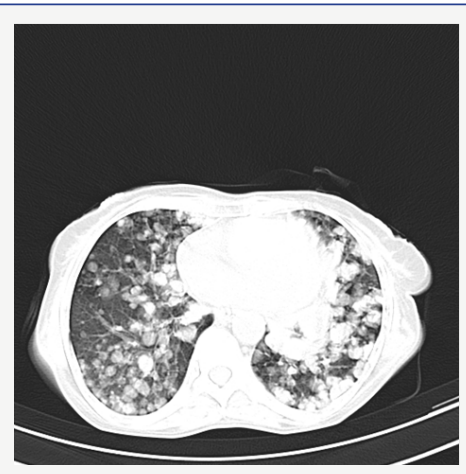

Figure 13: Shows cannon ball appearance of the lung.

d) HRCT Thorax (Figure 12\&13): Multiple small to moderate size "Canon Ball" Opacities scattered in both lung fields suggestive of multiple Pulmonary Metastasis.

\section{Histopathological Investigation}

Biopsy: Shows bone \& soft tissue with areas of necrosis and presence of highly pleomorphic cells having hyperchromatic nuclei \& prominent nucleoli. Mitotic activity is high. Biopsy is consistent with Osteosarcoma.

The patient was planned for neo adjuvant chemotherapy along with tumour resection but died during chemotherapy.

\section{Discussion}

Our case was found to be in the second peak of the bimodal peak of incidence seen in osteosarcoma. This was also seen in our search of the literature incidence of age, swelling [1] gender [2,3]. Tumor type [3] and location [4,5]. A thorough radiological examination is required to come to a prompt diagnosis of osteosarcoma. Increase in the awareness of the diagnostic features may lead to an early diagnosis and in doing so may improve the prognosis [6]. The final diagnosis can only be provided by histology and it should be kept in mind that osteosarcoma may mimic certain tumours histologically from which they originate and hence, it is essential to correlate the radiological and histological findings before arriving at a particular diagnosis. 
However, in our case the patient presented to us with a delay of 18 months and by that time the tumour had already metastatised to the lungs and the patient collapsed in the first cycle of chemotherapy itself. Petrikowski et al. [7] in a comparison of osteosarcoma, fibrous dysplasia and osteomyelitis found that the radiological picture provided much easier diagnosis and that the periosteal involvement always pointed towards osteosarcoma. Saving a patient from osteosarcoma is a team effort and it requires a good radiologist, pathologist and an oncosurgeon along with an orthopaedician to manage a case well and save the life of a cancer patient.

\section{References}

1. Regezi JA, Zarbo RJ, McClatchey KD, Courtney RM, Crissman JD (1987) Osteosarcomas and chondro sarcoma of the jaws: Immunohistochemical correlations. Oral Surg Oral Med Oral Pathol 64(3): 302-307.

2. Bennett JH, Thomas G, Evans AW, Speight PM (2000) Osteosarcoma of the jaws: A 30-year retrospective review. Oral Surg Oral Med Oral Pathol Oral Radiol Endod 90(3): 323-333.

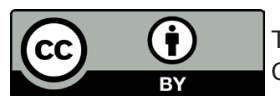

This work is licensed under Creative Commons Attribution 4.0 Licens
3. Forteza G, Colmenero B, Lopez-Barea F (1986) Osteogenic sarcoma of the maxilla and mandible. Oral Surg Oral Med Oral Pathol 62(2): 179184.

4. Zarbo RJ (1993) Malignant Non-odontogenic Neoplasms of the Jaws. In: Regezi JA, Schuibba J, editors. Oral Pathology Clinical Pathologic Correlations. Vol. 2. Philadelphia, Pennsylvania: W.B. Saunders Company pp. 436-457.

5. Mardinger O, Givol N, Talmi YP, Taicher S (2001) Osteosarcoma of the jaw, The Chaim Sheba Medical Center experience. Oral Surg Oral Med Oral Pathol Oral RadiolEndod 91(4): 445-451.

6. Givol N, Buchner A, Taicher S, Kaffe I (1998) Radiological features of osteogenic sarcoma of the jaws. A comparative study of different radiographic modalities. Dentomaxillofac Radiol 27(6): 313-320.

7. Petrikowski CG, Pharoah MJ, Lee L, Grace MG (1995) Radiographic differentiation of osteogenic sarcoma, osteomyelitis, and fibrous dysplasia of the jaws. Oral Surg Oral Med Oral Pathol Oral Radiol Endod 80(6): 744-750.

\section{Your next submission with Juniper Publishers will reach you the below assets}

- Quality Editorial service

- Swift Peer Review

- Reprints availability

- E-prints Service

- Manuscript Podcast for convenient understanding

- Global attainment for your research

- Manuscript accessibility in different formats

( Pdf, E-pub, Full Text, Audio)

- Unceasing customer service

Track the below URL for one-step submission

https://juniperpublishers.com/online-submission.php 